\title{
PENGARUH SENAM BUGAR LANSIA TERHADAP TEKANAN DARAH PENDERITA HIPERTENSI DI BPLU SENJA CERAH PANIKI BAWAH
}

\author{
${ }^{1}$ Victor.Moniaga \\ ${ }^{2}$ Damajanty H. C. Pangemanan \\ ${ }^{3}$ J.J.V.Rampengan
}

${ }^{1}$ Kandidat Skripsi Kedokteran Universitas Sam Ratulangi Manado
${ }^{2}$ Bagian Fisiologi Fakultas Kedokteran Universitas Sam Ratulangi Manado
Email: vicc_moniaga@yahoo.com

\begin{abstract}
Pressure is an essential force needed by the blood in order to distribute the blood throughout the entire human body by the blood vessels. Blood that is less viscous throughout the body is an important factor as it helps to absorb oxygen and other substances needed by the cells for growth. Factors such as age, sex, physical activities and lifestyle might affect blood pressure in the human body. The purpose of this study to determine the effect of exercise on blood pressure fit elderly patients with hypertension. This research is a field experiment with pre-post one group test plan. Data is then being analyzed with paired t sample test and statistics program by SPSS. Experimental sample of 30 people met the criteria of not having activities disorder that can inhibit movement of aerobic exercise causing it to be not optimal. Based on the experiment carried out, blood pressure varies during the 3 weeks of aerobic exercise where there is a decrease in blood pressure from the first week to the third week of aerobic exercise obtained systolic blood pressure in older adults showed differences decreased significantly, diastolic blood pressure increased and showed no significant differences but still normal limits.
\end{abstract}

Keywords : blood pressure, elderly aerobic.

\begin{abstract}
Abstrak: Tekanan darah adalah daya yang di perlukan agar darah dapat mengalir di dalam pembuluh darah dan beredar mencapai semua jaringan tubuh manusia. Darah dengan lancar beredar ke seluruh bagian tubuh berfungsi sangat penting sebagai media pengangkut oksigen serta zat-zat lain yang di perlukan bagi kehidupan sel-sel tubuh, Faktor-faktor yang mempengaruhi tekanan darah : umur,jenis kelamin,aktifitas fisik dan gaya hidup. Tujuan penelitian ini untuk mengetahui pengaruh senam bugar lansia terhadap tekanan darah penderita hipertensi. Jenis Penelitian ini bersifat eksperimental lapangan dengan rancangan one group pretest dan

Posttest design. Data dianalisis dengan uji sampel t berpasangan dengan menggunakan SPSS. Sampel penelitian berjumlah 30 orang yang memenuhi kriteria inklusi yaitu Tidak memiliki gangguan aktivitas yang menghambat gerakan senam bugar lansia sehingga tidak optimal. Dari awal sebelum melakukan kegiatan senam bugar lansia sampai minggu ke 3 perlakuan didapatkan tekanan darah sistolik pada lansia mengalami penurunan yang menunjukan perbedaan bermakna, sedangkan tekanan darah diastolik mengalami kenaikan dan tidak menunjukan perbedaan bermakna tapi masih dalam batas normal.
\end{abstract}

Kata Kunci: tekanan darah,senam bugar lansia

Tekanan darah adalah daya yang di perlukan agar darah dapat mengalir di dalam pembuluh darah dan beredar mencapai semua jaringan tubuh manusia(1). Darah dengan lancar beredar ke seluruh bagian tubuh berfungsi sangat penting sebagai media pengangkut oksigen serta zat-zat lain yang di perlukan bagi kehidupan sel-sel 
tubuh(1), selain itu darah juga berfungsi sebagai pengangkut sisa hasil metabolism yang tidak berguna lagi dari jaringan tubuh(1).

Lansia merupakan suatu bagian dari tahap perjalanan hidup manusia(2). Lansia bukan merupakan suatu penyakit namun merupakan tahap lanjut dari suatu proses kehidupan yang di tandai dengan penurunan kemampuan tubuh untuk beradaptasi dengan stress lingkungan(3). Pandangan sebagian masyarakat yang menganggap lansia sebagai manusia yang tidak mampu, lemah, dan sakit-sakitan,menyebabkan, segala aktivitas sangat dibatasi(2). Kondisi ini diperparah oleh tidak adanya waktu, tempat, dan kesempatan bagi lansia dalam melakukan aktivitas(2).

Aktivitas Menurut Sctotch yang dikutip oleh Darmojo dan Martono latihan yang baik untuk para lansia adalah dengan berolahraga (2). Jenis olahraga yang bisa dilakukan pada lansia antara lain adalah senam(2). Olahraga dengan teratur seperti senam bugar lansia dapat mencegah atau memperlambat kehilangan fungsional organ (2.4). Bahkan dari berbagai penelitian menunjukan bahwa latihan atau olahraga seperti senam lansia dapat mengeliminasi berbagai resiko penyakit seperti hipertensi, diabetes melitus, penyakit arteri koroner dan kecelakaan(4).

Olahraga yang cukup dapat menurunkan kecemasan, stres, dan menurunkan tingkat depresi(5). penurunan tersebut akan menstimulasi kerja sistem saraf perifer terutama parasimpatis yang menyebabkan vasodilatasi penampang pembuluh darah akan mengakibatkan terjadinya penurunan tekanan darah baik sistolik maupun diastotik(5).

\section{METODE PENELITIAN}

Jenis penelitian yang dilakukan adalah eksperimen Lapangan dengan rancangan penelitian one group pretest posttest design. Penelitian dilaksanakan di Balai Penyaluran Lanjut Usia Senja Cerah Manado antara bulan November 2012 sampai bulan Desember 2012. Populasi penelitian ini adalah semua pasien lanjut usia (lansia) di BPLU Senja Cerah. Sampel penelitian diambil dari sebagian dari populasi yang memenuhi kriteria inklusi berupa Tidak memiliki gangguan aktivitas yang menghambat gerakan senam bugar lansia sehingga tidak optimal dan bersedia untuk ikut dalam penelitian ini dan mendatangani informed consent.

Definisi operasional Tekanan Darah adalah kekuatan yang di perlukan agar darah dapat mengalir di dalam pembuluh darah dan beredar mencapai semua jaringan tubuh manusia. Pada penelitian ini klasifikasi tekanan darah >60 tahun 150/85, hipertensi 160/95. Senam Bugar lansia adalah senam intensitas ringan sampai sedang, bersifat menyeluruh dengan gerakan yang melibatkan sebagian besar otot tubuh, serasi sesuai gerak sehari-hari.

Hasil penelitian diuji dengan paired sample t-test untuk mengetahui ada tidaknya perbedaan pengamatan. Uji statistik ini dijalankan dengan menggunakan perangkat lunak SPSS.

\section{HASIL PENELITIAN}

Diambil dari sebagian populasi yang telah memenuhi kriteria inklusi sebanyak 30 orang. Subjek penelitian dipilih dengan melakukan penyaringan (screening). Sehingga faktor-faktor pengganggu dapat terkontrol. Faktor-faktor pengganggu yaitu sedang menderita sakit atau memiliki gangguan aktivitas yang menghambat gerakan senam bugar lansia sehingga tidak optimal. Berikut ini akan diuraikan hasil penelitian dalam bentuk tabulasi dan penjelasan.

\section{Distribusi frekuensi berdasarkan jenis kelamin}

Jumlah sampel terbanyak yang ikut serta dalam penelitian ini adalah perempuan dengan jumlah 21 orang atau sekitar $70 \%$ di bandingkan dengan laki-laki yang berjumlah 9 orang atau $30 \%$. 


\section{Distribusi frekuensi berdasarkan umur}

Jumlah sampel yang terbanyak adalah berumur 60-70 tahun yaitu 13 orang atau 43,33\% dan jumlah sampel yang paling sedikit adalah berumur 81-85 tahun atau $20 \%$ dari total jumlah sampel yang ada.

Tabel 1. Frekuensi berdasarkan jenis kelamin

\begin{tabular}{ccc}
\hline Jenis Kelamin & n & $\begin{array}{c}\text { Persentasi } \\
\text { (\%) }\end{array}$ \\
\hline Laki-laki & 9 & 30 \\
perempuan & 21 & 70 \\
JUMLAH & 30 & 100 \\
\hline
\end{tabular}

Tabel 2. Frkuensi berdasarkan umur

\begin{tabular}{ccc}
\hline $\begin{array}{c}\text { Umur } \\
\text { (tahun) }\end{array}$ & n & $\begin{array}{c}\text { Persentase } \\
(\mathbf{\%})\end{array}$ \\
\hline $60-70$ & 13 & 43.33 \\
$71-80$ & 11 & 36,67 \\
$81-85$ & 6 & 20 \\
TOTAL & 30 & 100 \\
\hline
\end{tabular}

\section{Hasil pengukuran Tekanan darah sebelum dan sesudah melakukan senam bugar lansia selama 3 minggu.}

Hasil penelitian menunjukan rata-rata nilai Tekanan Darah sebelum melakukan perlakuan adalah 152,33/78,67mmHG dan pada minggu ketiga setelah melakukan perlakuan Tekanan Darah mengalami penurunan menjadi 136,33/80,00 mmHG serta memiliki selisih $16 \mathrm{mmHG}$ sistolik dan 1,3 mmHG diastolik.

Tabel 3. Rata-rata tekanan darah sebelum dan sesudah perlakuan.

\begin{tabular}{ccccc}
\hline \multirow{2}{*}{ TEKANAN DARAH } & \multicolumn{4}{c}{ Hasil Pengukuran (mean \pm SD) } \\
\cline { 2 - 5 } & Sebelum & Sesudah & Selisih & P \\
\hline Sistolik (sebelum-sesudah) & $152,33 \pm 17,006$ & $136,33 \pm 20,254$ & 16 & 0,009 \\
Diastolik (sebelum-sesudah) & $78,67 \pm 11,137$ & $80,00 \pm 10,171$ & 1.3 & 0,436
\end{tabular}

\section{DISKUSI}

Olahraga adalah meningkatnya curah jantung yang akan disertai meningkatnya distribusi oksigen ke bagian tubuh yang membutuhkan, sedangkan pada bagian-bagian yang kurang memerlukan oksigen akan terjadi vasokonstriksi, misalnya traktus digestivus(6). Meningkatnya curah jantung pasti akan berpengaruh terhadap tekanan darah(6). Hasil penelitian menunjukkan karakteristik responden sebelum perlakuan yang hampir seluruhnya memiliki tekanan darah sistolik $\geq 140 \mathrm{mmHg}$ meskipun tekanan diastolik sebagian besar masih berada pada kisaran normal. Hal ini sesuai dengan teori yang menyatakan adanya hubungan penuaan dengan peningkatan tekanan darah, khususnya sistolik. Peningkatan tekanan darah sesuai pertambahan umur, sebagian besar berhubungan dengan perubahan pada keelastisan arterial dan arteriolar(7). Hasil penelitian setelah dilakukannya perlakuan yaitu menunjukkan terjadi penurunan tekanan darah sistolik sebelum perlakuan dengan minggu ke 3 perlakuan di peroleh selisih penurunan sebesar 16mmHG,hasil per $\mathrm{t}$ test dengan konfidensi interval 95\% $(\alpha<0,05)$ diperoleh nilai sistolik $\mathrm{p}=0,009$ $(\mathrm{p}<0,05)$. Hasil ini menunjukan adanya perbedaan bermakna pengukuran tekanan darah sistolik subjek sebelum perlakuan dengan minggu ketiga setelah perlakuan 
senam bugar lansia. Hasil penelitian ini sama seperti penelitian sebelumnya oleh Sri Thristyaningshi dkk jurnal gizi klinik Indonesia bahwa senam bugar lansia dapat menurunkan tekanan darah sistolik. Hal ini berhubungan dengan penurunan tahanan perifer(6).

Penurunan tahanan perifer dapat dijelaskan dari dua mekanisme yaitu terjadinya perubahan pada aktivitas sistem saraf simpatik dan respon vaskular setelah berolahrga. Pertama, secara neurohumoral menurunnya aktivitas sistem saraf simpatik pada pembuluh darah perifer sebagai petunjuk terjadi penurunan tekanan darah. Kedua, respon vascular mempunyai peranan penting pada penurunan tekanan darah setelah berolahraga. Olahraga diduga dapat mengubah respon vasokonstriktor (kontraksi pembuluh darah) kuat menjadi vasodilator (mengurangi vasokontriksi atau tekanan pada pembuluh darah) dan meningkatnya produksi nitrogen oksida (NO) (6).

Bagian diastolik terjadi kenaikan tekanan darah diastolik sebelum perlakuan dengan minggu ke 3 perlakuan diperoleh selisih kenaikan sebesar 1,3mmHG.hasil per $\mathrm{t}$ test diperoleh nilai diastolik $\mathrm{p}=0,436$ $(\mathrm{p}<0,05)$. Hasil ini menunjukan tidak ada perbedaan bermakna pengukuran tekanan darah diastolik subjek sebelum perlakuan dengan minggu ketiga setelah perlakuan senam bugar lansia.

Untuk mengidentifikasi penyebab adanya perbedaan hasil penelitian yang dilakukan oleh peneliti dan penelitian sebelumnya, Kelley dan Tran (2001), menyatakan bahwa untuk penurunan atau peningkatan tekanah darah diastolik dipengaruhi oleh lamanya waktu beristirahat sebelum dilakukan pengukuran tekanan darah setelah senam, besarnya peningkatan dalam penggunaan oksigen maksimum dan lamanya (dalam satuan minggu) senam dilakukan(8). Sehubungan dengan hal tersebut maka adanya peningkatan tekanan darah diastolik pada penelitian ini kemungkinan disebabkan karena waktu penelitian yang singkat yang memakan waktu 3 minggu sedangkan penelitian sebelumnya mencapai 4 minggu. Sehingga diperlukan waktu yang lebih panjang.

\section{SIMPULAN DAN SARAN}

Dari hasil penelitian pengaruh senam bugar lansia terhadap tekanan darah di simpulkan bahwa ,terjadi penurunan tekanan darah pada lansia yang melakukan aktivitas fisik senam bugar lansia .Hasil per $\mathrm{t}$ test dengan konfidensi interval 95\% $(\alpha<0,05)$ pada tekanan sistolik menunjukan perbedaan yang bermakna sedangkan pada diastolik mengalami peningkatan tapi masih dalam batas normal. sebaiknya dilakukan penelitian lanjut dengan jumlah sampel yang lebih banyak dan waktu yang cukup lama agar dapat mengetahui perbedaan yang signifikan senam bugar lansia terhadap tekanan darah.

\section{UCAPAN TERIMA KASIH}

Ucapan terima kasih disampaikan pada dr. H. I. S. Wungouw, MsAppSc, MMedEd, AIFM, AIFO dan dr. S. R. Marunduh, M.Med, AIFM. dan semua pihak yang baik secara langsung maupun tidak langsung telah menumbuhkan ide tau gagasan dalam pemikiran penulis sehingga dapat menyelesaikan artikel ini.

\section{DAFTAR PUSTAKA}

1. Olvista. Pengertian Tekanan Darah. Available form; http://olvista.com/kesehatan/pengertiantekanan-darah-tensi-darah/ .diunduh; 27 juni 2012. (diakses 21 oktober 2012).

2. Ekokurniad. Pengertian lansiaa. universitas muhammadiyah semarang

3. Efendy F, Makhfudli. Keperawatan Kesehatan Komunitas. Jakarta: Salemba Medika, 2009; p.243.

4. Gunawan L. Hipertensi tekanan darah tinggi (cet 8). Yogyakarta: Kanisius; 2001.

5. Senja L. Faktor-faktor yang berhubungan dengan tingkat kebugaran pada lansia. universitas muhammadiyah semarang.2009

6. SriThristyaningsih, Probosuseno, HerniAstuti. Senam bugar lansia berpengaruh terhadap daya tahan jantung 
paru, status gizi, dan tekanan darah. Jurnal gizi klinik Indonesia. juli 2011.

7. Sasliza W. Perbedaan penurunan tekanan darah pada penderita hipertensi usia pertengahan yang melakukan senam lansia dengan yang tidak melakukan senam lansia di wilayah kerja Puskesmas Pakan Kamis Kabupaten Agam 2012.

8. Kelley GA, Kristi AK, Zung VT. Aerobic exercise and resting blood pressure : a meta analytic review of randomized, controlled trials. Prev Cardiol. 2001;4(2):73-80. 